\title{
Hepatoprotective, cardioprotective, and renal-protective effects of organic and conventional grapevine leaf extracts (Vitis labrusca var. Bordo) on Wistar rat tissues
}

\author{
LÍVIA S. OLIBONI ${ }^{1}$, CAROLINE DANI ${ }^{1,2}$, CLÁUdIA FUNCHAL ${ }^{2}$, \\ JOÃO A. HENRIQUES ${ }^{1}$ and MIRIAN SALVADOR ${ }^{1}$ \\ ${ }^{1}$ Laboratório de Estresse Oxidativo e Antioxidantes, Instituto de Biotecnologia, Universidade de Caxias do Sul, \\ Rua Francisco Getúlio Vargas, 1130, 95070-560 Caxias do Sul, RS, Brasil \\ ${ }^{2}$ Laboratório de Bioquímica, Centro Universitário Metodista, IPA, Rua Pedro Salgado, 80, \\ 90420-060 Porto Alegre, RS, Brasil
}

Manuscript received on November 23, 2010; accepted for publication on August 29, 2011

\begin{abstract}
The purpose of this study was to evaluate the beneficial effects of organic and conventional grapevine (Vitis labrusca L.) leaf extracts in reducing hydrogen peroxide-induced stress in the liver, heart and kidney of Wistar rats by measuring lipids and proteins damages (carbonyl assay), as well as the activity of the antioxidant enzymes superoxide dismutase and catalase. The preincubation with $5 \mathrm{mg} / \mathrm{mL}$ of organic and conventional grapevine (Vitis labrusca L.) leaf extracts prevented both lipids and proteins oxidative damages in all tissues analyzed. The organic leaf extract was able to restore superoxide dismutase (kidney and liver) and catalase (heart) activities, which were modified by the treatment with $\mathrm{H}_{2} \mathrm{O}_{2}$. The conventional extract was able to restore only the catalase activity in liver and heart tissues. The beneficial effects of the $V$. labrusca leaf extract shown in this study could probably be important for formulating dietary supplements, as well as for developing new ingredients with improved antioxidant properties from other plant sources.
\end{abstract}

Key words: antioxidant activity, grapevine leaves, hepatoprotective, cardioprotective, renal-protective, Vitis labrusca.

\section{INTRODUCTION}

The formation of reactive species (RS) is a natural consequence of aerobic metabolism and is associated with oxygen homeostasis, i.e. the balance between constitutive oxidants and antioxidants (Seifried et al. 2007). Increased free radical production or reduced antioxidant defense response may give rise to increased oxidative stress (Halliwell and Gutteridge 2007), which has been associated with aging and a number of human chronic diseases such as cancer, liver, kidney and cardiovascular disorders (Seifried et al. 2007, Strayo et al. 2008).

There is an interrelated process to protect the cells against oxidative damages, which includes the superox-

Correspondence to: Mirian Salvador

E-mail: msalvado@ucs.br ide dismutase (SOD) and catalase (CAT) enzymes. The SOD activity catalyzes the dismutation of the superoxide anion $\left(\mathrm{O}^{-\bullet}\right)$ to oxygen and hydrogen peroxide, while the CAT activity converts hydrogen peroxide to water and molecular oxygen (Halliwell and Gutteridge 2007). Besides the enzymatic defenses, the antioxidant consumption in the diet has an important role in protecting against the development of diseases related to oxidative damages (Rubiolo et al. 2008).

Vitis vinifera leaves have been traditionally used as food and for treating hypertension (Basoglu et al. 2004), diarrhea, hemorrhage and varicose veins (Kosar et al. 2007), as well as inflammatory disorders (Bombardelli and Morazzonni 1995, Baytop 1999), all in humans, by the traditional medicine, and for reducing blood glucose levels in diabetics rats (Monagas et al. 
2006, Orhan et al. 2006). The leaves of $V$. vinifera have also shown hepatoprotective effects on acetaminophen induced hepatic DNA damage in rats (Montvale 2002). Currently, $V$. vinifera leaves are being employed to produce dietary ingredients commonly used to formulate dietary antioxidant supplements (Dávalos et al. 2003), and they are considered a cheap source for the extraction of antioxidant phenolic compounds (González-Paramás et al. 2004).

In South America, Vitis labrusca is the main species used for wine and juice production (Dani et al. 2007). It is also possible to find organic and conventional vineyards in the area. The organic production is characterized by restrictions against the use of synthetic pesticides and synthetic fertilizers (IFOAM 2005). This kind of product has shown some differences in the phenolic content when compared with conventional procedures (Asami et al. 2003, Dani et al. 2007). In another study from our group, organic and conventional grape juices showed an important hepatoprotective activity in rats (Dani et al. 2008). However, there are no data in the literature about grapevine leaves from different cultivars (organic and conventional).

Some cardiovascular, liver and kidney diseases are associated with high levels of oxidative stress. There is a hypothesis that lipid peroxidation is a key contributor to the progression and perhaps to the origin of cardiovascular diseases (Strobel et al. 2011) and to acute and chronic renal failure. Liver diseases remain one of the most serious health problems, and modern medicines have little to offer for the reduction of hepatic disorders. Therefore, many folk remedies of plant origin are evaluated for their possible hepatoprotective effects against different chemically induced liver damages in experimental animal models (Orhan et al. 2007).

Given these considerations, the aim of the present study was to investigate the protective effects of organic and conventional $V$. labrusca grape leaf extracts (GLET) in reducing the oxidative stress caused by $\mathrm{H}_{2} \mathrm{O}_{2}$ in kidney, liver and heart tissues of Wistar rats.

\section{MATERIALS AND METHODS}

\section{Chemicals}

2,4-dinitrophenylhydrazine was obtained from Riedelde-Haen (Seelze-Hannover, Germany). $\mathrm{H}_{2} \mathrm{O}_{2}$ and all other chemicals were purchased from E. Merck (Darmstadt, Germany).

\section{GRAPE LEAF EXTRACTS}

Leaves of V. labrusca, variety Bordo, from both conventional and organic production, were collected in November 2007 at the end of blooming, before fructification. The plant was identified at the herbarium of Centro Universitário Metodista IPA (Porto Alegre, RS, Brazil). The organic vines received the ECOVIDA certification (Dani et al. 2007). Leaves were dried under shade, powdered and extracted with $70 \%$ ethanol in a closed circuit at $70^{\circ} \mathrm{C}$ during $20 \mathrm{~h}$ in Soxhlet (Park et al. 1998). After this, the solvent present in the extract was evaporated under reduced pressure in a rotary evaporator for $5 \mathrm{~h}$. The powder obtained was diluted in water in a concentration of $0.1 \mathrm{~g} / \mathrm{mL}$ and used for the assays. The main phenolic compounds found in the GLET are shown in Table I.

\section{Tissue Preparation AND TREATMENT}

Ten-day-old male or female Wistar rats were obtained from our own breeding colony. They were maintained at approximately $25^{\circ} \mathrm{C}$, on a 12 -h light/12-h dark cycle, with free access to food and water. The "Principles of laboratory animal care" (NIH publication no. 80-23, revised 1996) were followed in all experiments, and our research protocol was approved by the Ethics Committee for Animal Experimentation of Centro Universitário Metodista. All efforts were made to minimize animal suffering and to use only the number of animals necessary to produce reliable scientific data. Animals were killed by decapitation without anesthesia and the kidney, liver and heart were rapidly excised on a Petri dish placed on ice. Tissues were weighed and kept chilled until homogenization, which was performed using a ground glass type Potter-Elvejhem homogenizer in $1.5 \% \mathrm{KCl}$. The homogenates were centrifuged at $800 \mathrm{~g}$ for $10 \mathrm{~min}$ at $4^{\circ} \mathrm{C}$, the pellet was discarded and the supernatants were immediately used (Seminotti et al. 2008). Kidney, liver and heart supernatants were treated with grape leaf extracts $(5 \mathrm{mg} / \mathrm{mL})$ for one hour, then $10 \mathrm{mM}$ hydrogen peroxide $\left(\mathrm{H}_{2} \mathrm{O}_{2}\right)$ was added, and the mixture was incubated for half an hour. As a control, aliquots were treated with $10 \mathrm{mM} \mathrm{H}_{2} \mathrm{O}_{2}$. Samples 
were incubated for $1 \mathrm{~h}$ at $37^{\circ} \mathrm{C}$ under agitation. After incubation, aliquots were taken to measure oxidative stress parameters. All experiments were conducted in accordance with the Guiding Principles of the Use of Animals in Toxicology, adopted by the Society of Toxicology in July 1989.

\section{OXIDATIVE Stress PARAMETERs}

Antioxidant activity of GLET, such as lipid and protein damages and SOD and CAT activities, was measured by in vitro assays. As an index of lipid peroxidation, we used thiobarbituric acid reactive species (TBARS), which is a sensitive method widely adopted for measuring lipid peroxidation, as previously described (Wills 1966). The protein oxidation was assessed by a reliable method based on the reaction of carbonyl groups with 2,4-dinitrophenylhydrazine (DNPH) to form a 2,4dinitrophenylhydrazone that could be measured spectrophotometrically as previously described (Levine et al. 1990). Equal amounts of protein samples without DNPH were used as controls. Results were expressed as $\mathrm{nmDNPH} / \mathrm{mg}$ of protein.

The antioxidant enzyme assays were performed on tissue homogenates as previously described (Latini et al. 2007). The SOD activity was spectrophotometrically determined by measuring the inhibition of selfcatalytic adrenochrome formation rate at $480 \mathrm{~nm}$ (Bannister and Calabrese 1987). The CAT activity assay was performed according to the method described by Aebi (1984). Protein concentrations were determined by the method of Bradford (1976) using bovine serum albumin as standard.

\section{StatisticAl ANALYSES}

Data were submitted to the analysis of variance (ANOVA) and means were compared using Tukey's test. Relationships among variables were assessed with Pearson's product-moment correlation coefficient. SPSS version 12.0 (SPSS, Chicago, IL) was used in all statistical analyses.

\section{RESULTS AND DISCUSSION}

Dietary antioxidants, including polyphenolic compounds, are considered beneficial because of their potential protective role in the pathogenesis of multiple diseases associated with oxidative stress such as cancer, inflammation and atherosclerosis (Mateos et al. 2005). Flavonoids are a large group of polyphenolic compounds present in grapes that show a wide range of biological activities. According to Kosar et al. (2007), Vitis vinifera leaf extracts contain different types of phenolic compounds such as tannins, flavonoids, procyanidins, anthocyanins and phenolic acids in the leaves and berries. In addition, in this study, hydroxycinnamic acids and flavonoids were found as the main compounds in all Vitis vinifera extracts.

According to the literature, polyphenols can inhibit lipid peroxidation, platelet aggregation, capillary permeability and the activity of some enzymes such as lipooxygenases and cyclooxygenases, which are associated with cardiovascular diseases (Mateos et al. 2005). In this work, the effects of GLET in preventing $\mathrm{H}_{2} \mathrm{O}_{2}$-induced oxidative stress were evaluated in the liver, heart and kidney of Wistar rats. Our results show that the treatment with $\mathrm{H}_{2} \mathrm{O}_{2}$ led to an increase in lipid peroxidation (TBARS) and protein damage (carbonyl) in all tissues assayed (Fig. 1), associated with SOD (in kidney and heart) and CAT (in all tissues) activity depletion (Fig. 2), thus altering the redox status by an overproduction of RS. The preincubation with GLET, from both conventional and organic production, prevents lipid and protein damages in all tissues (Fig. 1). The organic leaf extract was able to increase both SOD (kidney and liver) and CAT (heart) activities. The conventional leaf extract was able to restore only CAT activity in liver and heart tissues (Fig. 2).

In this context, the extracts from both organic and conventional $V$. labrusca leaves, which is the main species used in America to produce wines and grape juices (Seeram et al. 2008), were tested in heart, liver and kidney tissues of rats. It was observed that both extracts were able to reduce the lipid and protein $\mathrm{H}_{2} \mathrm{O}_{2}$-induced damage in all tissues (Fig. 1), indicating hepatoprotective, renal-protective and cardioprotective actions of GLET. A negative correlation between lipid peroxidation and total phenolic $(\mathrm{r}=-0.888, \mathrm{p}<0.01)$, flavonoids $(\mathrm{r}=-0.856, \mathrm{p}<0.01)$ and resveratrol $(\mathrm{r}=$ $-1.000, \mathrm{p}<0.05)$ contents in the kidney, and between lipid damages and resveratrol content $(\mathrm{r}=-0.999, \mathrm{p}<$ 0.01 ) in the liver was found. Protein damages were 


\section{$1 \mathrm{~A}$}

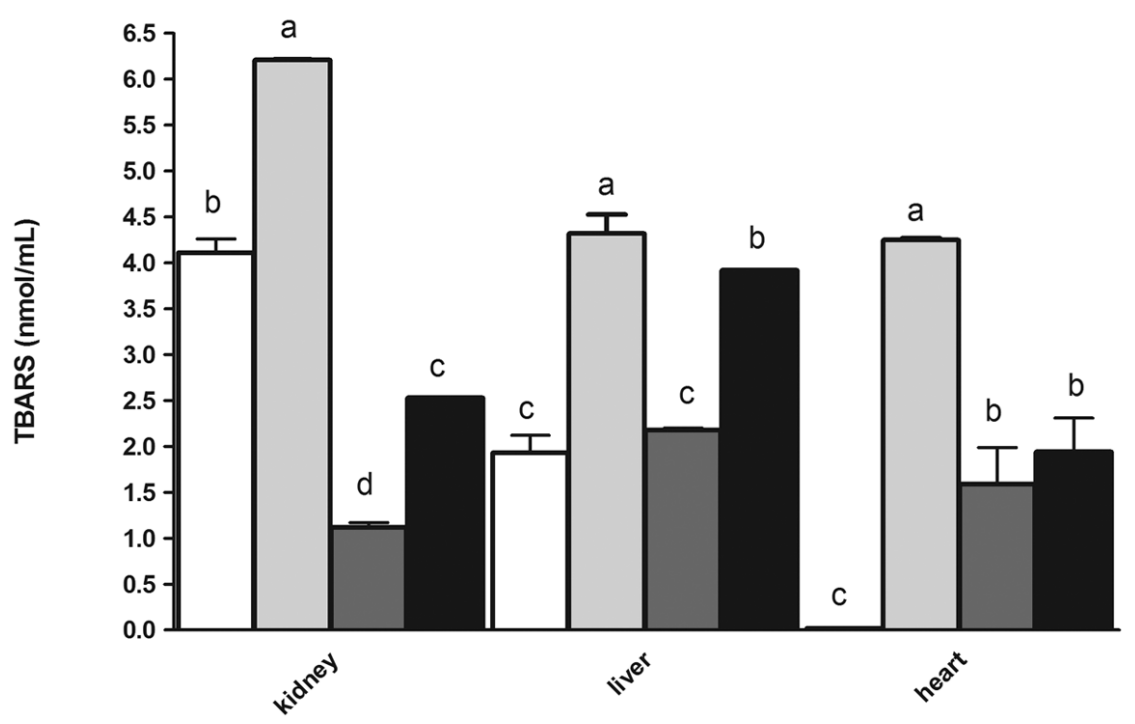

1B

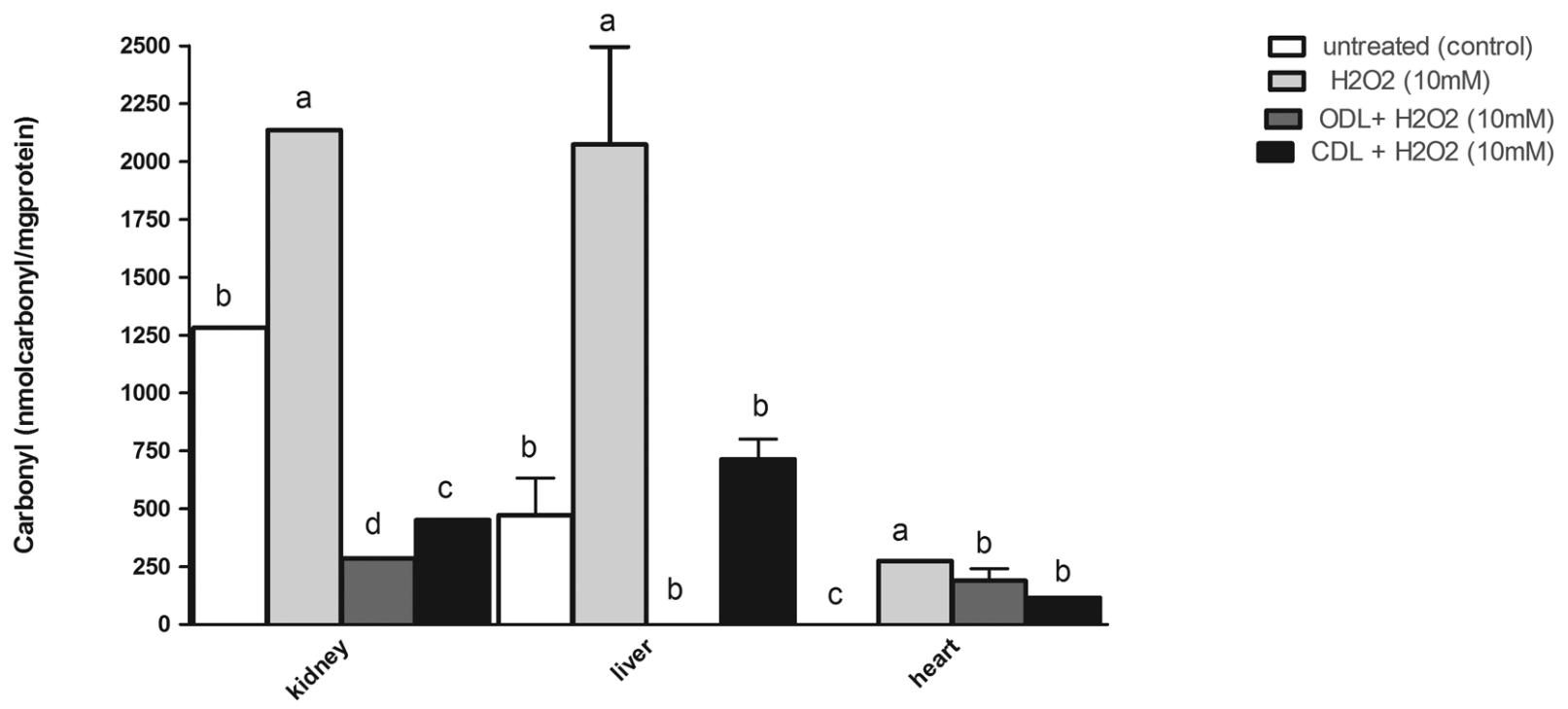

Fig. 1 - TBARS (A) and carbonyl (B) levels in kidney, liver and heart tissues of Wistar rats treated with organic and conventional grape leaf extracts. Data are mean \pm SD values of two independent experiments. *Different letters indicate a significant difference according to the analysis of variance and Tukey's post-hoc test $(\mathrm{p}=0.05)$ for each tissue evaluated; for example, $\mathrm{a}$ is different from $\mathrm{b}$.

negatively correlated with total phenolic $(\mathrm{r}=-0.908$, $\mathrm{p}<0.01)$, flavonoids $(\mathrm{r}=-0.899, \mathrm{p}<0.01)$ and resveratrol $(r=-1.000, p<0.05)$ content in the kidney, and with resveratrol $(\mathrm{r}=-0.985, \mathrm{p}<0.01)$ content in the liver. These correlations suggest that polyphenols contribute directly to the protective effect observed.
According to Pari and Suresh (2008), flavonoids found in grape leaves such as anthocyanins, catechin and non-flavonoids (stilbene) have been reported to have the ability to prevent $\mathrm{Fe}^{2+}$ and $\mathrm{Cu}^{2+}$ induced lipid peroxidation. In addition, according to Monagas et al. (2006), active constituents such as flavanols, flavanol 


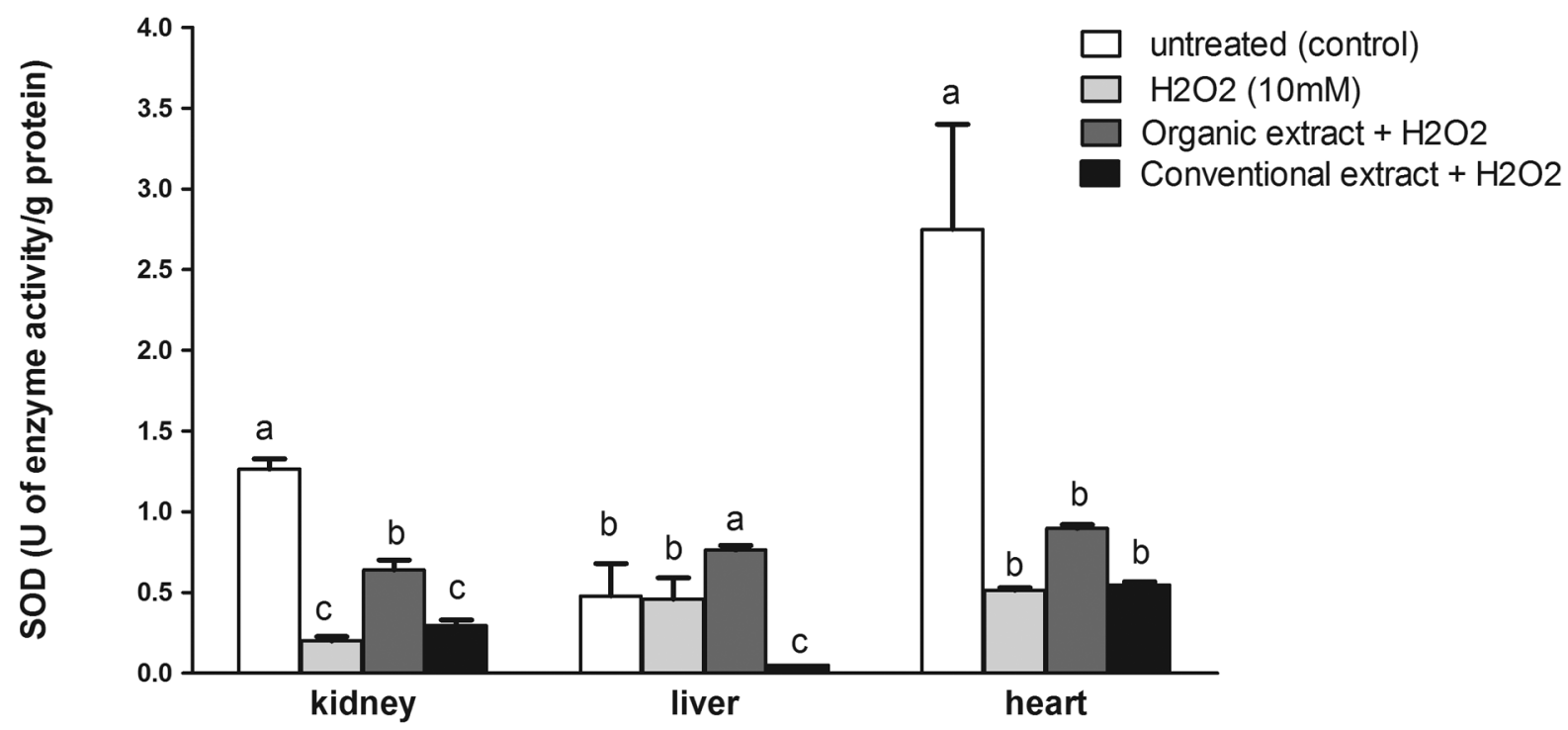

2B

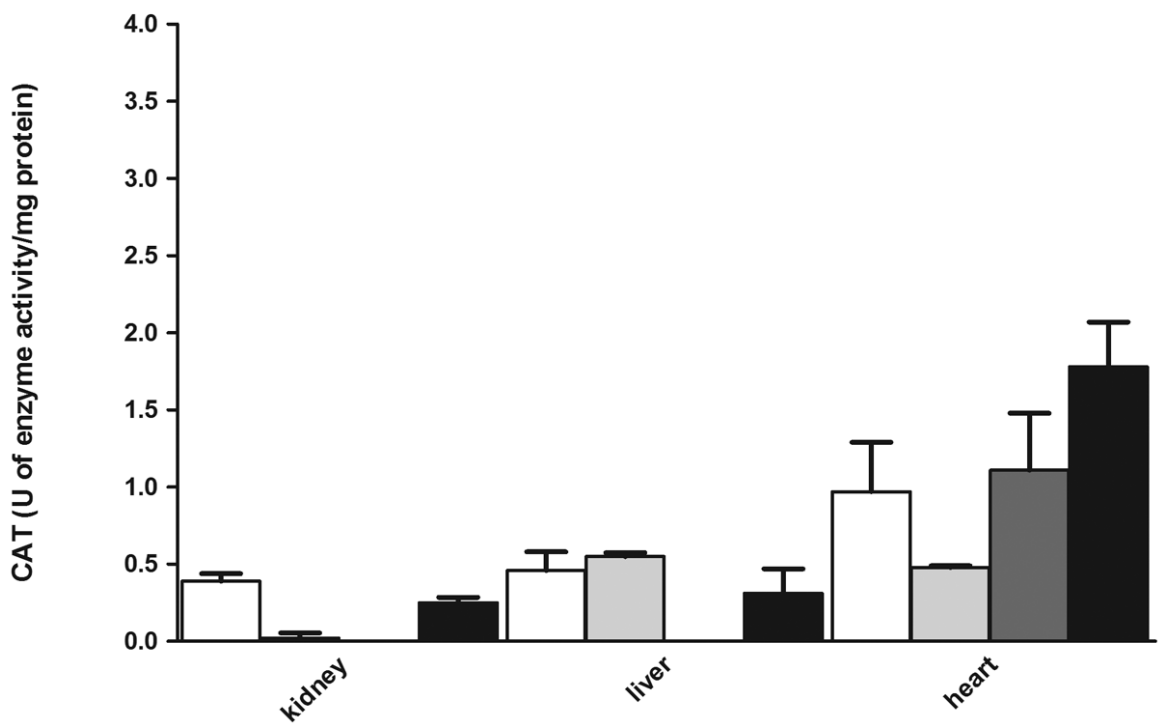

Fig. 2 - SOD (A) and CAT (B) activities in kidney, liver and heart tissues of Wistar rats treated with organic and conventional grape leaf extracts. Data are mean \pm SD values of two independent experiments. *Different letters indicate a significant difference; for example, $a$ is different from $b$ according to the analysis of variance and Tukey's post-hoc test $(\mathrm{p}=0.05)$ for each tissue evaluated.

oligomers and anthocyanidins were found in $V$. vinifera leaves. They have been reported as powerful antioxidants, and this might be the reason for the reversal of antioxidant levels in the tissues of alcohol-fed rats treated with leaf extracts.

It has already been shown that ethanol extracts of $V$. vinifera were able to induce a hepatoprotective ac- tion on carbon tetrachloride-induced acute liver damage in rats, which was attributed to the polyphenolic compounds (Orhan et al. 2007). Data about assays performed in kidney and heart tissues with grape leaf extracts are absent in the literature. However, it is known that grape seed extracts can reduce oxidative stress, which is elevated in cardiovascular and metabolic dis- 
eases (Falchi et al. 2006). Furthermore, a recent study showed that resveratrol and quercetin exerted protective effects in animal models of renal ischemia/reperfusion injury (Lo Presti et al. 2007).

According to Kosar et al. (2007), Vitis vinifera vine leaves contain hydroxycinnamic acid derivatives (via caffeic and chlorogenic acids) and flavonoids (via quercetin and its derivatives) as the main compounds responsible for antioxidant activities, as previously reported (Park and Cha 2003). In a recent study (Monagas et al. 2006), the chemical characterization of water and ethanolic extracts of Vitis vinifera leaves have been studied using HPLC method, and peonidin- 3- $O$-glucoside, quercetin-3- $O$-lucuronide and quercetin-3- $O$-glucoside have been found as major components of the water extract. Flavanols and flavanol oligomers and proanthocyanidins (condensed tannins) have been proven to possess powerful antioxidant activities, i.e. free radical scavenging activity and lipid peroxidation inhibition (Orhan et al. 2006). Moreover, according to Orhan et al. (2007), mainly condensed tannins and flavonoids were suggested to contribute to the antidiabetic activity and prevention of lipid peroxidation of Vitis vinifera leaves. However, in this study, no correlation was found between total phenolic content and antioxidant activity of the fractions, and we suppose that all compounds are important, not only one.

Grape leaf extracts showed different patterns in modulating the $\mathrm{H}_{2} \mathrm{O}_{2}$-induced enzyme activities, and it was found that the organic vine leaves were more effective in preventing oxidative damages (Fig. 2). Although both GLETs have similar total phenolic content, statistical differences in all flavonoid contents were observed. Moreover, naringin was found only in the conventional leaf extract. Organic GLET showed around 10 times more resveratrol than the conventional extract (Table I).

In fact, the SOD activity was positively correlated with resveratrol content $(\mathrm{r}=0.981, \mathrm{p}<0.05 ; \mathrm{r}=$ $0.999, \mathrm{p}<0.01 ; \mathrm{r}=0.997, \mathrm{p}<0.01)$ in kidney, liver and heart tissues, respectively, suggesting that resveratrol might be responsible, amongst other factors, for modulating this antioxidant defense. Polyphenols are also associated with the CAT activity. We found a positive correlation between the CAT activity and catechin $(\mathrm{r}=0.975, \mathrm{p}<0.05 ; \mathrm{r}=0.979, \mathrm{p}<0.05)$, quercetin $(\mathrm{r}=0.978, \mathrm{p}<0.05 ; \mathrm{r}=0.982, \mathrm{p}<0.05)$ and rutin $(\mathrm{r}=0.981, \mathrm{p}<0.05 ; \mathrm{r}=0.985, \mathrm{p}<0.05)$ contents, in kidney and liver tissues, respectively, and with total flavonoids $(\mathrm{r}=0.717, \mathrm{p}<0.05)$ content in the heart tissue.

The organic GLET seems to be more efficient than the conventional one in counteracting the lipid and protein damages induced by $\mathrm{H}_{2} \mathrm{O}_{2}$ in the kidney and liver (Fig. 1). These data agree with our previous studies with organic and conventional purple grape juice (Dani et al. 2007, 2008). One possible explanation for the better results obtained for the organic extract is that, as pesticides are not used, the plants are more susceptible to the action of phytopathogenic organisms, resulting in the production of larger amounts of phenolic compounds, such as resveratrol, as a mean to defend itself (Soleas et al. 1997, Bourn and Prescott 2002).

Different effects were also observed for each tissue assayed. Among other factors, these results might be due to: (a) the availability of substrates for peroxidation, (b) the presence/amount of peroxidation inducers, such as ascorbate, $\mathrm{Fe}^{2+}$, oxygen, initiators of free radical reactions and the functioning of the electron transport chain, which serve as a source of RS, (c) the levels of the antioxidant defense, and (d) the differences in the membrane lipid, such as fluidity and surface charge (Strayo et al. 2008). The beneficial effects of $V$. labrusca leaf extracts found in this study could probably be of importance for formulating dietary supplements, as well as for developing new ingredients with improved antioxidant properties from other plant sources. However, in order to suggest the potential therapeutic use of GLET in preventing liver, kidney and heart diseases, further studies will be necessary to better understand the biological benefits and to unveil the mechanism of this important protective effect.

\section{ACKNOWLEDGMENTS}

We are grateful to Luciana Serafini and Fabiana Agostini (Universidade de Caxias do Sul) for their assistance with the grape leaf extraction procedure; to Centro Universitário Metodista IPA (Porto Alegre, Rio Grande do Sul, Brazil) for helping in the identification of the plant; and to Universidade de Caxias do Sul (Caxias do Sul, Rio Grande do Sul, Brazil), Conselho Nacional de Desen- 
TABLE I

Phenolic content of organic and conventional grape leaf extracts ${ }^{1}$.

\begin{tabular}{|c|c|c|c|c|}
\hline $\begin{array}{c}\text { Grape } \\
\text { leaf } \\
\text { extracts }\end{array}$ & $\begin{array}{l}\text { Total phenolic } \\
\text { content (mg } \\
\text { gallic acid } / \mathrm{mL})\end{array}$ & $\begin{array}{l}\text { Flavonoids } \\
\text { ( } \mu \text { g rutin/ } \\
\text { mL) }\end{array}$ & $\begin{array}{l}\text { Catechin } \\
\text { (mg/g raw } \\
\text { extract) }\end{array}$ & $\begin{array}{c}\text { Resveratrol } \\
\text { (mg/g raw } \\
\text { extract) }\end{array}$ \\
\hline Organic & $20.2 \pm 1.80$ & $7.94 \pm 0.4$ & $3.64 \pm 0.01$ & $0.714 \pm 0.01$ \\
\hline Conventional & $19.0 \pm 0.05$ & $8.95 \pm 0.5^{*}$ & $4.30 \pm 0.03^{*}$ & $0.062 \pm 0.003^{*}$ \\
\hline $\begin{array}{c}\text { Grape } \\
\text { leaf } \\
\text { extracts }\end{array}$ & $\begin{array}{l}\text { Quercetin } \\
\text { (mg/g raw } \\
\text { extract) }\end{array}$ & $\begin{array}{c}\text { Rutin } \\
\text { (mg/g raw } \\
\text { extract) }\end{array}$ & $\begin{array}{c}\text { Kaempferol } \\
\text { (mg/g raw } \\
\text { extract) }\end{array}$ & $\begin{array}{c}\text { Naringin } \\
\text { (mg/g raw } \\
\text { extract) }\end{array}$ \\
\hline Organic & $5.86 \pm 0.15$ & $44.90 \pm 0.22$ & $1.37 \pm 0.10$ & ND \\
\hline Conventional & $6.74 \pm 0.08^{*}$ & $55.75 \pm 0.10^{*}$ & $1.43 \pm 0.15^{*}$ & $0.77 \pm 0.012^{*}$ \\
\hline \multicolumn{5}{|c|}{$\begin{array}{l}1 \text { data from Dani et al. 2009. ND: not detected. *Values statistically different from the organic } \\
\text { leaf extract according to the Student } t \text {-test }(P \leq 0.05) \text {. The total phenolic content was measured } \\
\text { using Singleton and Rossi's modification of the Folin-Ciocalteau colorimetric method (Singleton et } \\
\text { al. 1999). Flavonoids content were evaluated by vanillin assay according to Monagas et al. (2003). } \\
\text { Catechin, resveratrol, quercetin, rutin, kaempferol and naringin contents were measured by HPLC } \\
\text { according to Robards (2003) and Ector et al. (1996). }\end{array}$} \\
\hline
\end{tabular}

volvimento Científico e Tecnológico (CNPq) and Fundação de Amparo à Pesquisa do Estado do Rio Grande do Sul (FAPERGS) for their help and financial support during this research.

\section{RESUMO}

O objetivo deste estudo foi avaliar os efeitos benéficos de extratos de folhas de videira (Vitis labrusca L.) orgânicas e convencionais em reduzir o dano gerado pelo peróxido de hidrogênio no fígado, coração e rim de ratos Wistar, pela medida de danos a lipídios e a proteínas (Ensaio Carbonyl), como também a modulação sob a atividade das enzimas antioxidantes superoxido dismutase e catalase. A pré-incubação com $5 \mathrm{mg} / \mathrm{mL}$ de extratos de folhas de videira (Vitis labrusca $\mathrm{L}$.) orgânicas e convencionais previnem ambos danos oxidativos a lipídios e proteínas em todos os tecidos analisados. O extrato de folha orgânica foi capaz de restabelecer a atividade das enzimas superóxido dismutase (rim e fígado) e catalase (coração), as quais foram modificadas pelo tratamento com peróxido de hidrogênio. O extrato convencional foi capaz de restabelecer apenas a enzima catalase no fígado e no coração. Os efeitos do extrato da folha $V$. labrusca mostrados neste estudo, provavelmente, poderiam ser importantes para a formulação de suplementos dietéticos, bem como para o desenvolvimento de novos ingredientes com propriedades antioxidantes provenientes de outras plantas.
Palavras-chave: atividade antioxidante, folhas de videiras, hepatoproteção, cardioproteção, renal proteção, Vitis labrusca.

\section{REFERENCES}

Aebi H. 1984. Catalase in vitro. Method Enzymol 105: 121-126.

Asami DK, Hong YJ, BARrett D And Mitchell AE. 2003. Comparison of the total phenolic and ascorbic acid content of freeze-dried and air-dried marionberry, strawberry, and corn grown using conventional, organic, and sustainable agricultural practices. J Agr Food Chem 51: 1237-1240.

BANNister JV And CAlabrese L. 1987. Assays for SOD. Method Biochem Anal 32: 279-312.

Basoglu F, Sahin I, Korukluoglu M, Uylaser V, AKPINAR A AND CÜ O. 2004. Improvements in brineless processing of vine leaves. Acad Food 2: 7-12.

BAYTOP T. 1999. Therapy with Plants in Turkey. Istanbul University Publications, n. 3255 Turkey, 374 p.

BOMBARDELli E AND MORAZZONI P. 1995. Vitis vinifera L. Fitoterapia 66: 291-317.

Bourn D AND Prescott J. 2002. A comparison of the nutritional value, sensory qualities and food safety of organically and conventionally produced foods. $\mathrm{Crc} \mathrm{Cr}$ Rev Food Sci 42: 1-34. 
BRADFORD MM. 1976. A rapid and sensitive method for the quantification of microgram quantities of protein utilizing the principle of protein dye binding. Anal Biochem 7: $248-254$.

Dani C, Oliboni LS, Agostini F, Funchal C, Serafini L, Henriques JA And Salvador M. 2009. Phenolic content of grapevine leaves (Vitis labrusca var. Bordo) and its neuroprotective effect against peroxide damage. Toxicol In Vitro 24(1): 148-153.

Dani C, Oliboni ls, Pasquali M, Oliveira Mr, Umezu F, Salvador M, Moreira JC And HenriQUES JAP. 2008. Intake of purple grape juice as a hepatoprotective agent in Wistar rats. J Med Food 11: 127-132.

DANi C, Olibon LS, VANDERlinde R, Bonatto D, SALVADOR M AND HENRIQUes JAP. 2007. Phenolic content and antioxidant activities of white and purple juices manufactured with organically - or conventionally - produced grapes. Food Chem Toxicol 45: 2575-2580.

DÁvalos A, Gómez-Cordovés C And Bartolomé B. 2003. Commercial dietary antioxidant supplements assayed for their antioxidant activity by different methodologies. J Agr Food Chem 50: 5909-5914.

Ector BJ, Magee JB, Hegwood CP And Coign MJ. 1996. Resveratrol concentration in muscadine berries, juice, pomace, purees, seeds, and wines. Am J Enol Vitic 47(1): 57-62.

Falchi M, Bertelli A, lo Scalzo R, Morassut M, Morelli R, DAs S, Cui J AND DAs DK. 2006. Comparison of Cardioprotective Abilities between the Flesh and Skin of Grapes. J Agr Food Chem 54: 6613-6622.

GonzÁlez-PARAmÁs AM, Esteban-RuAno S, SANTOSBuelga C, Pascual-Teresa S and Rivas-GonzaLO JC. 2004. Flavanol content and antioxidant activity in winery products. J Agr Food Chem 52: 234-238.

Halliwell B and Gutteridge JMC. 2007. Free Radicals in Biology and Medicine, $4^{\text {th }}$ ed., Oxford: Clarendon Press.

INFOAM - INTERNATIONAL FEDERATION OF ORGANIC Agriculture Movements. 2005. Available in: $<$ http://www.ifoam.org > . Accessed in March 2009.

Kosar M, Küpeli E, Malyer H, Uylaser V, TÜrkben C AND BASER KHC. 2007. Effect of brining on biological activity of leaves of Vitis vinifera L. (cv. Sultani Cekirdeksiz) from Turkey. J Agr Food Chem 55: 45964603.

Latini A, Ferreira GC, Scussiato K, Schuck PF, Solano AF, Dutra-Filho CS, VARgas CR AND
WAJNER M. 2007. Cellular Induction of Oxidative Stress by Chronic and Acute Glutaric Acid Administration to Rats. Mol Neurobiol 27: 423-438.

Levine RL, Garland D, Oliver CN, Amici A, CliMENT I, LENZ AG, Ahn BW AND StadtMAn ER. 1990. Determination of carbonyl content in oxidatively modified proteins. Method Enzymol 186: 464-478.

Lo Presti R, Carollo C and Caimi G. 2007. Wine consumption and renal diseases: new perspectives. Nutrition 23: 598-602.

Mateos R, Lecumberri E, RAmos S, Goya L AND BRAVO L. 2005. Determination of malondialdehyde (MDA) by high-performance liquid chromatography in serum and liver as a biomarker for oxidative stress. Application to a rat model for hypercholesterolemia and evaluation of the effect of diets rich in phenolic antioxidants from fruits. J Chromatogr B 827: 76-82.

Monagas M, Hernández-Ledesma B, Gomez-Cordoves C AND Bartolomé B. 2006. Commercial dietary ingredients from Vitis vinifera L. leaves and grape skins: antioxidant and chemical characterization. J Agr Food Chem 54: 319-327.

Monagas M, NúÑEZ V, BARtolomé B AND GómeZCordoves C. 2003. Anthocyanin derived pigments in Graciano, Tempramillo, and Carbernet Sauvignon wines 446 produced in Spain. Am J Enol Vitic 54: 163-169.

MontVale NJ. 2002. PDR for Herbal Medicines, $2^{\text {nd }}$ ed., Medical Economics, p. 362-363.

Orhan DD, ORHAN N AND ERGUN F. 2007. Hepatoprotective effect of Vitis vinifera L. leaves on carbon tetrachloride-induced acute liver damage in rats. J Ethnopharmacol 112: $145-151$

Orhan N, Aslan M, Orhan DD, Ergun F and YesiLADA E. 2006. In-vivo assessment of antidiabetic and antioxidant activities of grapevine leaves (Vitis vinifera) in diabetic rats. J Ethnopharmacol 108: 280-286.

PARI L AND SURESH A. 2008. Effect of grape (Vitis vinifera L.) leaf extract on alcohol induced oxidative stress in rats. Food Chem Toxicol 46: 1627-1634.

PARK HJ AND Cha HC. 2003. Flavonoids from leaves and exocarps of grape Kyoho. Korean J Biol Sci 7: 327-330.

PARK YK, IKegaki M, ABReU JAS AND Alcici NMF. 1998. Estudo da preparação dos extratos de própolis e suas aplicações. Cienc Tecnol Aliment 18: 313-318.

RobARDS K. 2003. Strategies for the determination of bioactive phenols in plants, fruit and vegetables. J Chromatogr A 1000: 657-691. 
Rubiolo JA, Mithieux G And Vega FV. 2008. Resveratrol protects primary rat hepatocytes against oxidative stress damage. Activation of the Nrf2 transcription factor and augmented activities of antioxidant enzymes. Eur $\mathbf{J}$ Pharmacol 591: 66-72.

SeERAm NP ET AL. 2008. Pomegranate Juice and Extracts Provide Similar Levels of Plasma and Urinary Ellagitannin Metabolites in Human Subjects. J Med Food 11: 390-394.

Seifried DE, Anderson EI, Fisher JA And Milner A. 2007. Review of the interaction among dietary antioxidants and reactive oxygen species. J Nutr Biochem 18: $567-579$.

Seminotti B, Leipnitz G, Amaral AU, Fernandes CG, DA Silva LB, TONin AM, VAegas CR AND WAJNER M. 2008. Lysine induces lipid and protein damage and decreases reduced glutathione concentrations in brain of young rats. Int J Dev Neurosci 26: 693-698.
SINGLETON VL, ORTHOFER R AND LAMUELA-RAVENTÓS RM. 1999. Analysis of total phenols and other oxidation substrates and antioxidants by means of Folin-Ciocalteau reagent. In: Methods IN ENZYMOLOGY, OXIDANT And Antioxidant (PART A). San Diego: Academic Press, p. 159-178.

Soleas GJ, Diamandis EP And Goldberg DM. 1997. Resveratrol: a molecule whose time has come? And gone? Clin Biochem 30: 91-113.

Strayo D, AdHIKari S, TIlak-Jain J, MEnON VP AND Devasagayam TPA. 2008. Antioxidant activity of an aminothiazole compound: possible mechanisms. Chem Biol Interact 173: 215-223.

Strobel NA, Fassett RG, Marsh SA And Coombes JS. 2011. Oxidative stress biomarkers as predictors of cardiovascular disease. Int J Cardiol 147(2): 191-201.

WiLls ED. 1966. Mechanism of lipid peroxide formation in animal tissues. Biochem J 99: 667-676. 